\title{
Trade Blocks and the Gravity Model: A Study of Economic Integration among Asian Developing Countries
}

\author{
E. M. Ekanayake \\ Bethune-Cookman University \\ Amit Mukherjee \\ The Richard Stockton College of New Jersey \\ Bala Veeramacheneni \\ Farmingdale State College
}

\begin{abstract}
This paper analyzes the trade creation and trade diversion effects of the regional trade agreements (RTAs) in Asia and their effects on intra-regional trade flows using annual trade data for the period 1980-2009. The research will attempt to achieve the following objectives: (a) analyze the major RTAs in Asia and their effects on intra-regional trade flows. (b) use a gravity model to estimate the trade creation and trade diversion effects of various RTAs on trade flows within and across member groups; and (c) measure the effect of RTAs on members' trade with other Asian countries. The findings of this study are, for the most part, consistent with findings of previous studies on the Asian trade flows. The coefficients of real GDP, population, and distance had expected signs and magnitudes in all models estimated.
\end{abstract}

\footnotetext{
*Corresponding address: E. M. Ekanayake; School of Business, Bethune-Cookman University 640 Dr. Mary McLeod Bethune Blvd. Daytona Beach, FL 32114-3099, E-mail: ekanayakee@cookman.edu/ Amit Mukherjee; School of Business, The Richard Stockton College of New Jersey PO Box 195 Pomona, NJ 08240, E-mail: amit.mukherjee@stockton.edu / Bala Veeramacheneni, Department of History Economics and Politics, Farmingdale State College 2350 Broadhallow Road Farmingdale, NY, 11735-1021, E-mail: veeramb@farmingdale.edu

(C)2010-Center for Economic Integration, Sejong Institution, Sejong University, All Rights Reserved.
} 


\section{- JEL Classification: F14 and F15}

- Keywords: Trade Blocks, Gravity Model, Intra-Regional Trade, Asia.

\section{Introduction}

The number of regional trading arrangements (RTAs) or preferential trading agreements (RTAs) have grown dramatically since the early 1990s. By the end of 2009, there were over 220 agreements in force that had been notified to the World Trade Organization (WTO), and an additional 70 are estimated to be operational although not yet notified. According to the WTO, if RTAs reportedly planned or already under negotiation are concluded, the total number of RTAs in force might well approach 300 .

Theoretical work on RTAs has always highlighted that while the merchandise trade provisions of RTAs can boost trade among member countries, it is at the expense of trade among non-members. Therefore, whether it benefits a country to join a RTA depends on the cost structures in partner countries, compared with the cost structures in non-members. Viner (1950) recognized that the trade induced by a preferential trading agreement was of two types, which he called trade creation and trade diversion. Trade creation is the substitution in the importing country of a lower cost source of supply within the area for a more costly source and is, therefore, beneficial to the member countries and the world as a whole. In contrast, trade diversion is the substitution of a more costly source of supply within the area for a less costly source outside the area.

Many studies have investigated whether regional trade blocs raise the economic welfare of the integrating partners and the excluded countries. While all of these studies argue that trade creation and diversion are important in understanding which and how RTAs form, the effects of RTA formation are typically ambiguous, since the relative size of trade creation and diversion is in general indeterminate. The welfare effects of RTA formation and the size of trade creation and diversion are an empirical issue. We analyze empirically the trade creation or diversion effects of major RTAs in Asia. The paper uses a gravity model augmented with several sets of dummy variables to estimate the effect of various RTAs on trade flows within and across membership groupings in Asia as well as the effect of RTAs on members' trade with other Asian countries. Some researches have argued that although gravity models have been very frequently used in modeling 
Table 1. Regional Trade Agreements in Asia

\begin{tabular}{|c|c|c|}
\hline Agreement & Member Countries & Status \\
\hline $\begin{array}{l}\text { Association } \\
\text { of Southeast } \\
\text { Asian Nations } \\
\text { (ASEAN) }\end{array}$ & $\begin{array}{l}\text { Brunei-Darussalam, } \\
\text { Cambodia, China, Indonesia, } \\
\text { Laos, Malaysia, Myanmar, } \\
\text { Philippines, Singapore, } \\
\text { Thailand, and Viet Nam }\end{array}$ & $\begin{array}{l}\text { ASEAN was formed in } 1967 \text { by } \\
\text { Indonesia, Malaysia, the Philippines, } \\
\text { Singapore, and Thailand. Brunei-Darus- } \\
\text { salam joined in 1984, Vietnam in 1995, } \\
\text { Myanmar and Lao People's Democratic } \\
\text { Republic (PDR) in 1997, Cambodia in } \\
\text { 1999, and China in 2004. }\end{array}$ \\
\hline $\begin{array}{l}\text { Bangkok } \\
\text { Agreement } \\
\text { (BA) }\end{array}$ & $\begin{array}{l}\text { Bangladesh, China, Laos, } \\
\text { India, Republic of Korea, } \\
\text { and Sri Lanka }\end{array}$ & $\begin{array}{l}\text { The Bangkok Agreement, signed in } 1975 \text {, } \\
\text { is a preferential tariff arrangement that } \\
\text { promotes intra-regional trade through } \\
\text { exchange of mutually agreed concessions } \\
\text { by member countries. Membership was } \\
\text { extended to China in } 2002 \text {. }\end{array}$ \\
\hline $\begin{array}{l}\text { Economic } \\
\text { Cooperation } \\
\text { Organization } \\
\quad(E C O)\end{array}$ & $\begin{array}{l}\text { Afghanistan, Azerbaijan, } \\
\text { Iran, Kazakhstan, } \\
\text { Kyrgyz Republic, Pakistan, } \\
\text { Tajikistan, Turkey, } \\
\text { Turkmenistan, and Uzbekistan }\end{array}$ & $\begin{array}{l}\text { ECO was established in } 1985 \text { by Iran, } \\
\text { Pakistan and Turkey for the purpose of } \\
\text { promoting economic, technical and } \\
\text { cultural cooperation among the Member } \\
\text { States. Membership was extended to the } \\
\text { other seven members in } 1992 \text {. }\end{array}$ \\
\hline $\begin{array}{l}\text { South Asia } \\
\text { Association } \\
\text { for Regional } \\
\text { Cooperation } \\
\text { (SAARC) }\end{array}$ & $\begin{array}{l}\text { Bangladesh, India, } \\
\text { Pakistan, Maldives, } \\
\text { Nepal and Sri Lanka }\end{array}$ & $\begin{array}{l}\text { SAARC was established in } 1985 \text { by } \\
\text { Bangladesh, Bhutan, India, Maldives, Nepal, } \\
\text { Pakistan and Sri Lanka. The } \\
\text { agreement on SAARC Preferential Trading } \\
\text { Arrangement (SAPTA) was signed in } 1993 .\end{array}$ \\
\hline
\end{tabular}

Source: World Trade Organization.

international trade flows, they have not yet been successfully used in capturing the trade creation and diversion effects of liberalization agreements.

Table 1 presents the major regional trade agreements in Asia and their current status. Of the four regional trade agreements, ASEAN is the oldest and largest agreement. In addition to these agreements, there are a several bilateral preferential trade agreements.

Table 2 shows the intra-block trade within the major regional trade agreements in Asia between 1970 and 2008. Even though intra-block trade of Asian RTAs increased between 1970 and 2008, they were not significant changes. They are quite low with the exception of ASEAN.

The degree of regional integration through trade in Asia has been rising fast over the last twenty years. However, in 2008, inter-regional trade share in Asia was much lower than the European Union's share of $67.1 \%$ and of $49.5 \%$ for the North 
Table 2. Intra-Block Trade in Asian RTAs, 1970-2008 (\%)

\begin{tabular}{|c|c|c|c|c|}
\hline Year & ASEAN & Bangkok Agreement & $\mathrm{ECO}$ & SAARC \\
\hline 1970 & 22.4 & 2.8 & 2.2 & 3.2 \\
\hline 1971 & 24.1 & 2.3 & 1.7 & 3.3 \\
\hline 1972 & 21.0 & 3.0 & 1.7 & 5.1 \\
\hline 1973 & 18.8 & 3.7 & 2.5 & 6.3 \\
\hline 1974 & 16.2 & 1.7 & 4.5 & 4.2 \\
\hline 1975 & 16.7 & 2.1 & 4.0 & 4.7 \\
\hline 1976 & 15.0 & 1.5 & 3.7 & 4.0 \\
\hline 1977 & 15.0 & 1.5 & 6.4 & 4.5 \\
\hline 1978 & 15.9 & 1.7 & 4.4 & 4.6 \\
\hline 1979 & 17.1 & 1.7 & 3.5 & 4.8 \\
\hline 1980 & 17.3 & 1.7 & 6.3 & 5.7 \\
\hline 1981 & 17.7 & 1.8 & 5.2 & 5.9 \\
\hline 1982 & 20.2 & 1.9 & 7.1 & 4.9 \\
\hline 1983 & 20.9 & 2.01 & 0.1 & 4.1 \\
\hline 1984 & 18.7 & 2.71 & 0.2 & 5.1 \\
\hline 1985 & 18.5 & 1.9 & 9.9 & 4.9 \\
\hline 1986 & 16.8 & 1.7 & 5.2 & 4.5 \\
\hline 1987 & 17.7 & 1.3 & 6.3 & 4.4 \\
\hline 1988 & 17.6 & 1.3 & 4.8 & 4.2 \\
\hline 1989 & 17.8 & 1.5 & 3.7 & 3.9 \\
\hline 1990 & 18.9 & 1.6 & 3.2 & 3.5 \\
\hline 1991 & 19.7 & 3.3 & 3.2 & 3.7 \\
\hline 1992 & 20.1 & 4.0 & 5.2 & 4.2 \\
\hline 1993 & 21.3 & 6.1 & 7.2 & 3.8 \\
\hline 1994 & 24.3 & 6.0 & 7.4 & 4.1 \\
\hline 1995 & 24.4 & 6.8 & 7.9 & 4.7 \\
\hline 1996 & 24.4 & 7.6 & 7.1 & 4.6 \\
\hline 1997 & 23.9 & 8.0 & 7.5 & 4.5 \\
\hline 1998 & 21.0 & 7.0 & 6.8 & 5.2 \\
\hline 1999 & 21.7 & 7.3 & 5.8 & 4.5 \\
\hline 2000 & 23.0 & 8.0 & 5.6 & 4.7 \\
\hline 2001 & 22.3 & 8.6 & 5.5 & 5.5 \\
\hline 2002 & 22.7 & 9.3 & 5.9 & 5.5 \\
\hline 2003 & 24.71 & 0.1 & 6.6 & 6.6 \\
\hline 2004 & 24.91 & 1.0 & 6.6 & 6.5 \\
\hline 2005 & 25.3 & 11.1 & 7.6 & 6.7 \\
\hline 2006 & 24.9 & 10.8 & 8.4 & 6.4 \\
\hline 2007 & 25.2 & 11.2 & 9.0 & 6.5 \\
\hline 2008 & 25.4 & 11.0 & 8.3 & 6.3 \\
\hline
\end{tabular}

Key:

ASEAN: Association of South-East Asian Nations ECO: Economic Cooperation Organization

SAARC: South Asian Association for Regional CooperationSource: United Nations Conference on Trade and Development (UNCTAD), Handbook of Statistics 2009.Table 2. Intra-Block Trade in Asian RTAs, 1970-2008 (\%) 
American Free Trade Agreement (NAFTA). It is also interesting to note that there have not been any significant change in the intra-block trade after the given RTA was implemented. For example, when ECO and SAARC were established in 1985, there have not been any significant changes in trade share in the following year or two. Therefore, it is important to analyze the level of trade creation and trade diversion effects of the major RTAs in Asia. The specific objectives of this study are to: (a) analyze the major RTAs in Asia and their effects on intra-regional trade flows; (b) use a gravity model to estimate the trade creation and trade diversion effects of various RTAs on trade flows within and across member groups; and (c) measure the effect of RTAs on members' trade with other Asian countries.

The remainder of the paper is organized as follows: Section II provides a review of the existing literature on this topic. Section III gives a brief description of the methodology used and data sources. Section IV discusses our analysis and findings while Section V offers some conclusions.

\section{Survey of Previous Studies}

This section summarizes the previous studies that used gravity model to estimate the effects of regional trading agreements on trade flows among member and nonmember countries. For a more detailed literature review, the reader is directed to any of a number of surveys of various approaches to the study of RTAs, including Panagariya (1999, 2000), DeRosa (1998), Harrison, Rutherford and Tarr (2003), Robinson and Thierfelder (2002), Scollay and Gilbert (2000), and Lloyd and MacLaren (2004).

The popularity of the gravity model is relatively recent. It was used during the 1960s and 1970s to estimate trade flows but was criticized because it lacks a strong theoretical foundation. Tinbergen (1962), Poyhonen (1963), and Linneman (1966) provided initial specifications and estimates of the determinants of trade flows while Aitken (1973) applied it to RTAs. Anderson (1979) provided a rigorous economic justification, deriving a reduced-form gravity equation from a general equilibrium model incorporating the properties of expenditure systems. Bergstrand (1985) and Deardorff (1997) also provided partial theoretical foundations for the gravity equation, although none of the models generated exactly the same equation generally used in empirical work. Due to a revival of interest among economists in the interconnectedness of economics and geography, the gravity model has again become popular. 
Gravity models were first applied to international trade by Tinbergen (1962) and Pöyhönen (1963). Tinbergen developed the model to determine the normal or standard pattern of international trade that would prevail among 42 countries in the absence of trade barriers. Besides the standard GM, Tinbergen also estimated other models including dummy variables for trade agreements and the presence of a common border among trading countries.

Later, Leamer and Stern (1970) derived these relationships from a probability model of transactions, but none relied on standard trade theories. Several authors in search for a theoretical basis came up with models that are based on increasing returns. In particular, Anderson (1979) used Armington preferences in a model of homogenous goods to derive a role for transport costs.

Bergstrand $(1985,1989)$ developed this analysis further within the increasing returns framework. Later, Helpman (1981) and Helpman and Krugman (1985) integrated monopolistic competition into a Heckscher-Ohlin framework. More recently, Deardorff (1998) derived gravity equation from two cases of the HeckscherOhlin theory. These papers now provide the previously missing theoretical underpinnings for the gravity model. Consequently, Evenett and Keller (1998) showed how the data can be used to discriminate between the two alternative trade theories and thus found theoretical support for both in gravity models.

Based on the Helpman and Krugman (1985) model that successfully incorporates monopolistic competition of the increasing returns theory into a Heckscher-Ohlin framework, a number of empirical tests explaining bilateral trade flows have been performed (see for example, Balassa, 1986; Helpman, 1987; Balassa and Bauwens, 1987). Other authors used per capita income to express the level of economic development (Koo and Karamera, 1991; Carrillo and Li, 2002). Models that include population are often referred to as augmented gravity models (Cheng and Wall, 2004). Other variables that are commonly used in gravity models are dummy variables to control for cultural similarity among trade partners, such as language or historical relationships such as colonialism. Growing empirical literature finds that historical linkages are important determinants of international trade flows (see Frankel, Stein and Wei, 1995; Frankel, 1997; and Eichengreen and Inrwin, 1998). Lagged bilateral trade flows are significant in determining current trade in a large cross-section of countries, after controlling for income and distance.

Trade statistics confirm that the magnitude of intra-trade within the following three regional groupings, namely, the European Union, Asia-Pacific and North America, has been disproportionately high. One plausible explanation behind this 
apparent bias towards intra-regional trade in these three country groups is geographical proximity among the countries. The immediate consequence of geographical proximity is reduction in transport costs, short delivery time, less interest payments on export credits and low spoilage. Both Krugman (1991) and Summers (1991) have opined that the disproportionate intra-trade in above-named three country groups is largely due to proximity, and the other traits associated with proximity. They are wedded to the concept that proximity promotes trade. Krugman (1991) goes further and argues that the three trading blocs are welfare enhancing natural groupings. This naturally means that there are some "unnatural" trade groupings where partners do not have proximity but are far apart. $\mathrm{He}$ provided the example of a trading arrangement between the United Kingdom and the members the Commonwealth as an "unnatural" trading arrangement. The argument supporting this hypothesis is that due to less or no distance between trading partners, intra-continental RTAs are likely to be more trade creating than trade diverting.

Frankel and Wei (1997) provide an extensive examination of possible RTAs in Asia-Pacific. They also considered a sequence of "nested country groupings" in Asia, like ASEAN, East Asia, and South Asia and the whole of Asia. In their gravity model exercise, they measured the log of distance between two major cities-usually the capital cities-of the respective countries for their empirical model. They also added a dummy "adjacent" variable to indicate when two countries shared a common border. In another similar study, Frankel, Stein, and Wei (1994) tried to test with a more thorough measure of distance that took into account land and sea routes. The results of both the studies tended to be similar. Frankel and Wei (1997) took GNP in product form because it is empirically well established in bilateral trade regressions and can be justified by the modern theory of trade under imperfect competition. Countries a priori choose larger countries to trade with because they offer greater variety of goods to choose from than smaller countries. Also common language tends to facilitate trade by enhancing exporters' and importers' understanding of each others' cultures, commercial and legal systems, which have a great deal of influence on trade. To capture these effects Frankel and Wei (1997) included dummy variables that took the value of one if the country pair in question had a favorable impact on trade due to these effects, and zero if they did not.

The inferences of Frankel and Wei (1997) may be summarized as follows. As posited by the gravity model, geography matters. Distance has an economically 
and statistically large effect on trade. As distance increased by $1 \%$, trade declined by $0.5 \%$. The "adjacency" dummy showed that two countries with a common land border have a larger volume of trade than two otherwise identical countries. Another important conclusion was that common language or past colonial connections facilitated trade; it brought in 50\% more trade than otherwise.

Thus, using gravity model they reached two vitally important conclusions. First, East and Southeast Asian economies clearly show certain inward bias among themselves. Second, even after controlling for a special Asia effect, East and Southeast Asian economies as a group appear to trade more among themselves than one would expect based on their economic and geographic characteristics. Adding the Hong Kong and Singapore dummies does not change the qualitative feature of the picture.

\section{Methodology and Data}

This study uses an augmented gravity model to analyze the trade flows in Asia. Gravity models were introduced to economic theory in the 1960s. Linneman's (1966) seminal study applied a gravity model to analyze the factors that explain trade for a sample of 80 countries. Gravity models have been augmented with variables representing factors that could either facilitate or impede trade.

This article follows numerous authors and specifies the following gravity equation which controls for the basic determinants of international trade. Since the literature on standard gravity models are well known, this study does not discuss the theoretical foundation of gravity models. Following Athukorala and Yamashita (2006) and Kabir and Salim (2010), our specification of the gravity model is:

$$
\begin{aligned}
\ln X_{i j}= & \beta_{0}+\beta_{1} \ln G D P_{i}+\beta_{2} \ln G D P_{j}+\beta_{3} \ln P O P_{i}+\beta_{4} \ln P O P_{j}+\beta_{5} \ln D_{i s t} \\
& +\beta_{6} \ln R F E_{i j}+\beta_{7} \text { SIM }_{i j}+\beta_{8} \text { Border }_{i j}+\beta_{9} \text { Language }_{i j} \\
& +\beta_{10} \text { Colony }_{i j}+\beta_{11} R T A(I)+\beta_{12} R T A(O)+\beta_{13} \text { BTA }+\beta_{14} \text { ASEN } \\
& +\beta_{15} \text { BA }+\beta_{17} \text { SAARC }+\beta_{18} T+u_{i j}
\end{aligned}
$$

where $X_{i j}$ is the exports from country $i$ to country $j ; G D P_{i}$ is the real gross domestic product of country $i$;GDP $P_{j}$ is the real gross domestic product of country $j ; P O P_{i}$ is the population of country $i, P O P_{j}$ is the population of country $j ; D_{i s t} i_{j}$ is the geographical or economic distance between the two countries; $R F E_{i j}$ is the relative factor endowment between country $i$ and country $j$; $S I M_{i j}$ is the similarity 
index; Border is a dummy variable which takes the value 1 if the two countries share a contiguous border and zero otherwise; Language is a dummy variable which takes the value 1 if the two countries share a common language and zero otherwise; Colony is a dummy variable that equals 1 if the exporting country is a former colony of importing country or if the two countries share a common colonial linkage and zero otherwise; $R T A(I)$ is a binary variable which is unity if two countries belong to the same regional trade agreement and zero otherwise; $R T A(O)$ is a binary variable which is unity if country $i$ belong to a regional trade agreement and country $j$ does not, or vice versa and zero otherwise; BTA is a dummy variables that equals 1 if country $i$ and country $j$ has a bilateral trade agreement and zero otherwise; $A S E A N$ is a dummy variable which is unity if the country is a member of the Association of Southeast Asian Nations and zero otherwise; $B A$ is a dummy variable which is unity if the country is a member of the Bangkok Agreement and zero otherwise; $E C O$ is a dummy variable which is unity if the country is a member of the Economic Cooperation Organization and zero otherwise; SAARC is a dummy variable which is unity if the country is a member of the South Asia Association for Regional Cooperation and zero otherwise; $T$ is a set of dummy variables to capture year-specific "fixed" effects; and $u_{i j}$ is a normally distributed error term. Thus, the dummy RTA(I) measures the degree of trade-creation effects of the regional trade agreement between members, while the dummy $R T A(O)$ captures the degree of trade-diverting effects between members and nonmembers, compared to the "normal" bilateral trade flows.

According to Frankel (1993), real GDP is included to capture the factors associated with the level of economic development. It also captures the productive capacity of the exporting country and the purchasing power of the importing country. The coefficients of the real GDP variables are expected to be positive.

Population variables represent the size of the countries and are expected to have positive signs. According to Venables (1987) and Krugman (1980), the larger countries are better able to absorb imports than smaller countries and are better able to experience economies of scale and thus develop a comparative advantage in their export industries than are smaller countries.

The coefficient of the distance variable ( Dist $_{i j}$ ) is expected to be negative. This is a proxy for transportation costs and time, access to market information, access to markets, and other factors that make it difficult for nations to engage in trade. The anticipated sign on all ten dummy variables is positive, reflecting the idea that proximity, common language, historical links, and regional trading agreements are 
trade creating networks. However, the expected sign of the dummy variable $R T A(O)$ can either be positive or negative.

The relative factor endowment variable $\left(R F E_{i j}\right)$ is defined as the absolute value of the difference between natural logarithm of per capita GDPs between country $i$ and country $j$. The choice of this variable as an explanatory variable is based on the standard comparative advantage explanation of trade. This variable aims to capture technology differences between countries in explaining trade patterns. Though this variable is generally measured as the absolute value of the difference between natural logarithm of capital-labor ratio, due to the unavailability of data per capita GDP is used in place of capital-labor ratio. The expected sign of this variable is positive. Recent studies that used this method include Egger (2002), Baltagi et al. (2003), Serlenga and Shin (2007), and Kabir and Salim (2010). Thus, relative factor endowment is defined as:

$$
R F E_{i j}=\left|\ln P G D P_{i}-\ln P G D P_{j}\right|
$$

Following Breuss and Egger (1999), Egger (2000, 2002), and Serlenga and Shin (2007), the similarity index is defined as:

$$
S I M_{i j}=\ln \left[1-\left(\frac{G D P_{i}}{G D P_{i}+G D P_{j}}\right)^{2}-\left(\frac{G D P_{j}}{G D P_{i}+G D P_{j}}\right)^{2}\right]
$$

The expected sign of the similarity index variable is positive. This is due to the fact that similarity with respect to GDP per capita implies increased similarity in size of country-specific product diversity in the differentiated goods sector and that leads to an increased trade volume.

This study uses annual data from 1980 to 2009 . The dependent variable used in the analysis is exports from country $i$ to country $j$. The data on exports for the study period of 1980-2009 are from the UN Commodity Trade Statistics (UN Comtrade) database and from International Monetary Fund, Direction of Trade Statistics database. Data on population are from International Monetary Fund, International Financial Statistics Yearbook. Information on real gross domestic product is from the UNCTAD, Handbook of Statistics 2009 database and from International Monetary Fund, World Economic Outlook database, April 2010. Information on per capita gross domestic product is from the International Monetary Fund, World Economic Outlook database, April 2010. The distance variable is obtained from the World Bank, Trade, Production, and Protection 1976-2004 database. 


\section{Empirical Results}

We estimate the model with annual data for 19 Asian countries for the period 1980 to 2009. They include Bangladesh, Brunei Darussalam, Cambodia, China, Hong Kong, India, Indonesia, Japan, Korea, Malaysia, Maldives, Myanmar, Nepal, Pakistan, Philippines, Singapore, Sri Lanka, Thailand and Vietnam. We analyze the trade flows of these 19 countries to a sample of 64 countries. The list of the countries in the full sample is given in the Appendix. We estimated four sets of regression models to measure the effects of regional trade agreements in Asia during the four periods: 1980-2009, 1980-1989, 1990-1999, and 2000-2009. The model was estimated using ordinary least squares (OLS) with country dummies to capture country-specific fixed effects. Since there was strong evidence of heteroskedasticity, we derived consistent variance-covariance standard errors of the regression coefficients using the Huber-White consistent variance-covariance estimator. The results are reported in Table 3. The conventional variables behave very much the same way as the model predicts, and the estimated coefficients are statistically significant. The adjusted $R^{2}$ values range from a low of 0.544 to a high of 0.604 . These values are acceptable for a cross-sectional study and are comparable to those obtained in other studies employing the gravity model to examine intra-regional trade flows.

The coefficients of the real GDP variables for both countries are positive in all models estimated. They are also statistically significant at the $1 \%$ level of significance. The population coefficients are negative and statistically significant in all models. The distance variable has the expected negative sign and is highly significant in all models estimated. The results for the distance variable provide strong support for the hypothesis that transportation and other distance-related costs are an important determinant of trade flows.

The Border variable has the expected positive sign in all models. However, this variable is not statistically significant in any of the four models. The common language dummy is statistically significant, with the expected positive sign in all cases. The common colony dummy is statistically significant, with the expected positive sign in all cases. The coefficient on relative factor endowment variable is statistically significant in three of the four cases and has the expected sign in three time periods. Its positive sign suggests that bilateral trade flows are related positively to inter-country differences in the level of technological advancement. The coefficient on similarity index variable is statistically significant in three of the 
Table 3. Effects of RTAs on Trade Flows in Asia

\begin{tabular}{|c|c|c|c|c|}
\hline Variable & 1980-2009 & 1980-1989 & 1990-1999 & 2000-2009 \\
\hline Constant & $\begin{array}{c}-37.418^{* * *} \\
(0.56)\end{array}$ & $\begin{array}{l}-44.702^{\text {*** }} \\
(1.05)\end{array}$ & $\begin{array}{c}-34.655^{* * *} \\
(0.92)\end{array}$ & $\begin{array}{c}-32.807 \\
(0.79)\end{array}$ \\
\hline $\ln \left(G D P_{i}\right)$ & $\begin{array}{l}2.618^{* * *} \\
(0.02)\end{array}$ & $\begin{array}{l}3.219^{* * *} \\
(0.05)\end{array}$ & $\begin{array}{l}2.365^{* * *} \\
(0.40)\end{array}$ & $\begin{array}{l}2.256^{\text {*** }} \\
(0.04)\end{array}$ \\
\hline $\ln \left(G D P_{j}\right)$ & $\begin{array}{l}1.614^{* * *} \\
(0.02)\end{array}$ & $\begin{array}{l}1.824^{* * *} \\
(0.06)\end{array}$ & $\begin{array}{l}1.557^{* * *} \\
(0.42)\end{array}$ & $\begin{array}{l}1.513^{* * *} \\
(0.04)\end{array}$ \\
\hline $\ln \left(P O P_{i}\right)$ & $\begin{array}{l}-0.372^{* * *} \\
(0.02)\end{array}$ & $\begin{array}{c}-0.812^{* * *} \\
(0.04)\end{array}$ & $\begin{array}{l}-0.080^{* *} \\
(0.03)\end{array}$ & $\begin{array}{l}-0.205^{* * *} \\
(0.03)\end{array}$ \\
\hline $\ln \left(P O P_{j}\right)$ & $\begin{array}{l}-0.597^{* * *} \\
(0.03)\end{array}$ & $\begin{array}{c}-0.864^{* * *} \\
(0.06)\end{array}$ & $\begin{array}{l}-0.583^{\text {*** }} \\
(0.05)\end{array}$ & $\begin{array}{l}-0.406^{* * *} \\
(0.03)\end{array}$ \\
\hline$R F E_{i j}$ & $\begin{array}{r}0.001 \\
(0.01)\end{array}$ & $\begin{array}{l}-0.001^{* * *} \\
(0.00)\end{array}$ & $\begin{array}{l}0.001^{* * *} \\
(0.00)\end{array}$ & $\begin{array}{l}0.001^{\text {*** }} \\
(0.00)\end{array}$ \\
\hline$S_{I} M_{i j}$ & $\begin{array}{l}0.221^{* * *} \\
(0.05)\end{array}$ & $\begin{array}{l}0.525^{* * *} \\
(0.10)\end{array}$ & $\begin{array}{l}-0.183^{* *} \\
(0.08)\end{array}$ & $\begin{array}{r}0.057 \\
(0.07)\end{array}$ \\
\hline $\ln ($ Distance $)$ & $\begin{array}{l}-0.689^{* * *} \\
(0.05)\end{array}$ & $\begin{array}{l}-0.629^{* * *} \\
(0.09)\end{array}$ & $\begin{array}{l}-0.703^{\text {*** }} \\
(0.08)\end{array}$ & $\begin{array}{l}-0.775^{* * *} \\
(0.06)\end{array}$ \\
\hline Border & $\begin{array}{r}0.110 \\
(0.17)\end{array}$ & $\begin{array}{c}0.339 \\
(0.34)\end{array}$ & $\begin{array}{r}0.076 \\
(0.29)\end{array}$ & $\begin{array}{c}0.096 \\
(0.24)\end{array}$ \\
\hline Languge & $\begin{array}{l}1.999^{* * *} \\
(0.11)\end{array}$ & $\begin{array}{l}2.166^{* * *} \\
(0.21)\end{array}$ & $\begin{array}{l}2.164^{* * *} \\
(0.19)\end{array}$ & $\begin{array}{l}1.088^{* * *} \\
(0.16)\end{array}$ \\
\hline Colony & $\begin{array}{l}1.040^{* * *} \\
(0.23)\end{array}$ & $\begin{array}{l}1.148^{* *} \\
(0.45)\end{array}$ & $\begin{array}{c}0.762^{*} \\
(0.39)\end{array}$ & $\begin{array}{l}1.685^{\text {*** }} \\
(0.33)\end{array}$ \\
\hline$R T A(I)$ & $\begin{array}{l}2.347^{* * *} \\
(0.11)\end{array}$ & $\begin{array}{l}2.375^{* * *} \\
(0.22)\end{array}$ & $\begin{array}{l}2.401^{* * *} \\
(0.19)\end{array}$ & $\begin{array}{l}2.274^{* * *} \\
(0.16)\end{array}$ \\
\hline$R T A(O)$ & $\begin{array}{l}-0.803^{* * *} \\
(0.13)\end{array}$ & $\begin{array}{l}-1.342^{* * *} \\
(0.26)\end{array}$ & $\begin{array}{l}-0.852^{\text {*** }} \\
(0.22)\end{array}$ & $\begin{array}{c}-0.096 \\
(0.53)\end{array}$ \\
\hline$B T A$ & $\begin{array}{l}-0.174 \\
(0.19)\end{array}$ & $\begin{array}{r}0.050 \\
(0.39)\end{array}$ & $\begin{array}{l}-0.157 \\
(0.34)\end{array}$ & $\begin{array}{l}-0.243 \\
(0.26)\end{array}$ \\
\hline$A S E A N$ & $\begin{array}{l}1.517^{* * *} \\
(0.09)\end{array}$ & $\begin{array}{l}1.989^{* * *} \\
(0.18)\end{array}$ & $\begin{array}{l}1.260^{* * *} \\
(0.15)\end{array}$ & $\begin{array}{l}1.346^{* * *} \\
(0.13)\end{array}$ \\
\hline$B A$ & $\begin{array}{l}1.453^{* * *} \\
(0.07)\end{array}$ & $\begin{array}{l}2.055^{* * *} \\
(0.13)\end{array}$ & $\begin{array}{l}1.431^{* * *} \\
(0.12)\end{array}$ & $\begin{array}{l}1.014^{* * *} \\
(0.11)\end{array}$ \\
\hline$E C O$ & $\begin{array}{l}-0.293^{*} \\
(0.15)\end{array}$ & $\begin{array}{l}-0.593^{*} \\
(0.30)\end{array}$ & $\begin{array}{r}-0.163 \\
(0.26)\end{array}$ & $\begin{array}{l}-0.082 \\
(0.22)\end{array}$ \\
\hline$S A A R C$ & $\begin{array}{l}1.564^{* * *} \\
(0.09)\end{array}$ & $\begin{array}{l}3.395^{* * *} \\
(0.19)\end{array}$ & $\begin{array}{l}0.977^{* * *} \\
(0.17)\end{array}$ & $\begin{array}{c}0.243^{*} \\
(0.14)\end{array}$ \\
\hline Adjusted $R^{2}$ & 0.578 & 0.544 & 0.566 & 0.608 \\
\hline Observations & 36.570 & 12.190 & 12.190 & 12.190 \\
\hline$F$ & 1.091 .7 & 558.7 & 609.3 & 725.7 \\
\hline RMSE & 1.12 & 1.08 & 1.04 & 1.20 \\
\hline
\end{tabular}

Note: The standard errors of the regression coefficients have been derived using the Huber-White consistent variance-covariance estimator. RMSE is the Root Mean Square Errors. Statistical significance is denoted as *** for $1 \%$ level, ** for $5 \%$ level, and * for $10 \%$ level. 
four cases and has the expected sign in three time periods.

The estimated coefficient of the dummy variable, $R T A(I)$, has the expected positive sign and statistically significant in all four cases. This variable is expected to measure the degree of trade-creation effects of the regional trade agreement between members. The export enhancement effect of Asian regional trade agreements, calculated by $\left[\exp \left(\beta_{11}\right)-1\right] \times 100$, turns out to be $945.4 \%$. The estimated coefficient of the dummy variable, $R T A(O)$, has a negative sign in all four cases. This variable is expected to capture the degree of trade-diverting effects between members and nonmembers, compared to the "normal" bilateral trade flows.

The coefficient of the bilateral trade agreements dummy is statistically insignificant in all four cases. It also has the unexpected negative sign in three of the four cases. Three of the four dummy variables for membership in regional trade agreements, namely ASEAN, BA, and SAARC, have the expected positive signs and all are statistically significant. The dummy variable representing the fourth regional trade agreement, ECO, has the unexpected negative sign. This may be due to the fact that only 2 of the 19 Asian countries are members of this agreement. In sum, all coefficients of regional dummy variables are mostly positive and significant, indicating that multilateral trade agreements tend to enhance more trade than bilateral trade agreements.

\section{Summary and Conclusions}

Employing the gravity model in the analysis of intra-regional trade flows in Asia reveals some interesting observations concerning Asian trade and integration arrangements, such as the importance of language and culture as determinants of trade resistance. The regression results provide interesting results that mostly support the gravity estimates conducted on other economic blocs.

The main purpose of this paper was to understand the effects of regional trade agreements on trade flows among Asian countries. The analytical procedure includes an augmented gravity model to estimate export equations using combined time-series/cross-country data for the period 1980 to 2009. A sample of 19 Asian countries was chosen for the empirical analysis. The results are meaningful in terms of explaining the pattern of Asian trade, which support the theoretical model. The real GDP of both importers and exporters positively influence the bilateral trade. The population of both importers and exporters negatively influence the 
bilateral trade. Consistent with other studies using the gravity model, distance is found to be negative and statistically significantly correlated with Asian exports.

The findings of this study are, for the most part, consistent with findings of previous studies on Asian trade flows. The coefficients of per capita GDP, population, and distance had expected signs and magnitudes in all models estimated. This confirms the results of other studies. The rapidly evolving economic and political climates provide many opportunities for the investigation of the success of economic integration in Asia.

Received 2 November 2009, Revised 27 July 2010, Accepted 8 May 2010

\section{References}

Anderson, J. E., van Wincoop, E. (2003), Gravity with Gravitas: A Solution to the Border Puzzle, American Economic Review, 93(1), pp. 170-192.

Anderson, J. E. (1979), A Theoretical Foundation for the Gravity Equation, American Economic Review, 69(1), pp. 106-116.

Athukorala, P., Yamashita, N. (2006), Production fragmentation and trade integration: East Asia in a Global Context, North American Journal of Economics and Finance, 17, pp. 233-256.

Bergstrand, J. H. (1985), 'The Gravity Equation in International Trade: Some Microeconomic Foundations and Empirical Evidence', The Review of Economics and Statistics, 67, pp. 474-81.

Brada, J. C., Mendez, J. A. (1983), Regional Economic Integration and the Volume of Intra-Regional Trade: A Comparison of Developed and Developing Country Experience, Kyklos, 36, pp. 92-105.

Breuss, F., Egger, P.(1999), How Reliable Are Estimations of East-West Trade Potentials Based on Cross-Section Gravity Analyses?, Empirica, 26, pp. 81-94.

Carrillo, C., Li, C. A. (2002), Trade Blocks and the Gravity Model: Evidence from Latin American Countries, Working Paper, Department of Economics, University of Essex, UK.

Das, D. K. (2001), Regional Trading Agreements and the Global Economy: An Asia Pacific Perspective, Center for International Development, Harvard University, Cambridge, Massachusetts, USA.

Deardorff, A. V. (1998), Determinants of Bilateral Trade: Does Gravity Work in a Neoclassical World?, in Jeffrey A. Frankel (ed.), Regionalization of the World Economy, Chicago: University of Chicago Press, 7-22.

DeRosa, D. A. (1998), Regional Integration Arrangements: Static Economic Theory, Quantitative Findings and Policy Guidelines, Policy Research Working Paper No. 2007, World Bank. 
Egger, P. (2008), On the Role of Distance for Bilateral Trade, The World Economy, 31(5), pp. 653-662.

Egger, P. (2000), A Note on the Proper Econometric Specification of the Gravity Equation, Economics Letters, 66, pp. 25-31.

Egger, P. (2002), An Econometric View on the Estimation of Gravity Models and the Calculation of Trade Potentials, World Economy, 25, pp .297-312.

Eichengreen, B., Irwin, D. A. (1995), Trade Blocs, Currency Blocs and Reorientation of World Trade in the 1930s, Journal of International Economics, 38(1), pp. 1-24.

Evans, C. L. (2000), The Economic Significance of National Border Effects, mimeo, Federal Research Bank of New York.

Evenett, S. J., Keller, W. (1998), On the Theories Explaining the Success of the Gravity Equation, NBER Working Paper No. 6529, Cambridge, MA: National Bureau of Economic Research.

Feenstra, R., Markusen, J., Rose, A. (2001), Using the Gravity Equation to Differentiate Among Alternative Theories of Trade, Canadian Journal of Economics, 34(1), pp. 430-447.

Frankel, J. (1997), Regional Trading Blocs in the World Economic System, Institute for International Economics.

Frankel, J., Romer, D. (1999), Does Trade Cause Growth?, American Economic Review, 89(3), pp. 379-399.

Frankel, J., Stein, E., Wei, S. (1995), Trading Blocs and the Americas, Journal of Development Economics, 47(1), pp. 61-95.

Freund, C. (2000), Different Paths to Free Trade: The Gains from Regionalism, Quarterly Journal of Economics, 115(4), pp. 1317-1341.

Garman, G., Petersen, J., Gilliard, D. (1998), Economic Integration in the Americas: 19751992, Journal of Applied Business Research, 14(3), pp. 1-12.

Greene, W. H. (2003), Econometric Analysis, Fifth Edition, New Jersey: Prentice Hall.

Harrison, G., Rutherford, T., Tarr, D. (2003), Rules of Thumb for Evaluating Preferential Trading Arrangements: Evidence from Computable General Equilibrium Assessments, World Bank Working Paper 3149, October.

Helliwell, J. F. (1996), Do National Borders Matter for Quebec's Trade?, Canadian Journal of Economics, 26(3), pp. 507-522.

Helliwell, J. F. (1998), How Much Do National Borders Matter?, Washington, D.C.: The Brookings Institution.

Kabir, M., Salim, R. (2010), Can Gravity Model Explain BIMSTEC's Trade?, Journal of Economic Integration, 25(1), pp. 144-156.

Kawai, M. (2004), Trade and Investment Integration for Development in East Asia: A Case for the Trade-FDI Nexus, ABCDE European Meeting, Brussels.

Kawai, M. (1997), Japan's Trade and Investment in East Asia, in D. Robertson (ed.), East Asian Trade after the Uruguay Round, Cambridge: Cambridge University Press, pp. 209-226.

Krugman, P. (1991), The Move Toward Free Trade Zones, in Policy Implications of Trade 
and Currency Zones, Kansa City, Wyoming, Federal Reserve Bank of Kansas City, pp. 7-41.

Lee, H., Roland-Holst, D. (1998), Prelude to the Pacific Century: Overview of the Region, in Lee, H. and D. Roland-Holst (eds.), Economic Development and Cooperation in the Pacific Basin, Cambridge: Cambridge University Press, pp. 3-36.

Limao, N., Venables, A. (2001), Infrastructure, Geographical Disadvantage, Transport Costs, and Trade, The World Bank Economic Review, 15(3), pp. 451-479.

Lloyd, P. J., MacLaren, D. (2004), Gains and Losses from Regional Trading Agreements: A Survey, Economic Record, 80(251), pp. 445-467.

Martinez-Zarzoso, I., Nowak-Lehmann, F. (2003), Augmented Gravity Model: An Empirical Application to Mercosur-European Union Trade Flows, Journal of Applied Economics, 6(2), pp. 291-316.

McCallum, J. (1995), National Borders Matter: Canada-US Regional Trade Patterns, American Economic Review, 85(3), pp. 615-623.

Olarreaga, M., Soloaga, I. (1998), Endogenous Tariff Formation: The Case of Mercosur, The World Bank Economic Review, 12(2), pp. 297-320.

Panagariya, A. (2000), Preferential Trade Liberalization: The Traditional Theory and New Developments, Journal of Economic Literature, 38(2), pp. 287-331.

Panagariya, A. (1999), The Regionalism Debate: An Overview, World Economy, 22(4), pp. 477-511.

Panagariya, A. (1996), The Free Trade Area of the Americas: Good for Latin America?, World Economy, 19, pp. 485-515.

Roessler, F. (1993), The Relationship between Regional Integration Agreements and the Multilateral Trade Order, in K. Anderson and R. Blackhurst (eds.), Regional Integration and the Global Trading System, New York: Harvester Wheatsheaf.

Robinson, S., Thierfelder, K. (2002), Trade Liberalisation and Regional Integration: The Search for Large Numbers, Australian Journal of Agricultural and Resource Economics, 46, pp. 585-604.

Scollay, R., Gilbert, J. (2000), Measuring the Gains from APEC Trade Liberalization: An Overview of NGE Assessments, World Economy, 23(3), pp. 175-97.

Serlenga, L., Shin, Y. (2007), Gravity Models of Intra-EU Trade: Application of the CCEP-HT Estimation in Heterogeneous Panels with Unobserved Common TimeSpecific Factors, Journal of Applied Econometrics, 22, pp. 361-81.

Soloaga, I., Winters, L. A. (2001), How has Regionalism in the Nineties Affected Trade?, North American Journal of Economics and Finance, 12, pp. 1-29.

Urata, S. (2001), Emergence of an FDI-Trade Nexus and Economic Growth in East Asia, in J. Stiglitz and S. Yusuf (eds.), Rethinking the East Asian Miracle, New York: Oxford University Press, pp. 407-459.

Wei, S. J. (1996), Intra-National versus International Trade: How Stubborn are Nations in Global Integration?, NBER Working Paper No. 5531, Cambridge, MA: National Bureau of Economic Research.

World Trade Organization (1995), Regionalism and the World Trading System, Geneva. 
Yeats, A. (1998), Does Mercosur's Trade Performance Raise Concerns about the Effects of Regional Trade Arrangements?, The World Bank Economic Review, 12(1), pp. 128.

\section{Appendix}

Table 1. Countries Included in the Gravity Model Sample

\begin{tabular}{lll}
\hline Argentina & Indonesia & Poland \\
Australia & Iran & Portugal \\
Austria & Ireland & Qatar \\
Bahrain & Italy & Romania \\
Bangladesh & Japan & Russia \\
Belgium & Jordan & Saudi Arabia \\
Brazil & Kenya & Singapore \\
Brunei Darussalam & Korea, Republic of & South Africa \\
Cambodia & Kuwait & Spain \\
Canada & Malaysia & Sri Lanka \\
Chile & Maldives & Sweden \\
China, Hong Kong SAR & Mexico & Switzerland \\
China, P. R. of & Morocco & Syria \\
Czech Republic & Myanmar & Thailand \\
Denmark & NepalT & unisia \\
Egypt & Netherlands & Turkey \\
Finland & New Zealand & United Arab Emirates \\
France & Nigeria & United Kingdom \\
Germany & Norway & United States \\
Ghana & Pakistan & Uruguay \\
Greece & Panama & Viet Nam \\
Hungary & Peru & Yemen, Republic of \\
India & Philippines & \\
\hline
\end{tabular}

